\title{
Transforming Spaces: A Framework for the Identification and Analysis of Adolescents' No-Go Areas in Vienna
}

\author{
Thomas SCHAUPPENLEHNER, Renate EDER, \\ Anna HÖGLHAMMER and Andreas MUHAR \\ Universität für Bodenkultur, Vienna / Austria · thomas.schauppenlehner@boku.ac.at
}

This contribution was double-blind reviewed as full paper.

\begin{abstract}
The availability and usability of public space in urban fabric is important for adolescents, as they can use these places in the absence of parental control or impacts from school. Nevertheless, several studies point out, that particular public places often have a negative connotation for young people. The project Transforming Spaces identifies adolescents' negatively associated places in Vienna, and the motives behind those perceptions, by applying a participatory multi-perspective research approach. Participatory GIS-methods are used to locate these No-Go areas and to analyse their spatial distribution. Interviews, focus groups, and artistic approaches are applied to identify and reflect the motives of negative perceptions. Furthermore the comparison of an external view on negatively associated places with an internal view should help to reduce barriers and to transform subjective spatial connotations. This paper presents the methodological framework of the project and discusses challenges as well as benefits of the selected multi-methodological approach.
\end{abstract}

\section{Introduction}

A headline in the Kurier, a major Austrian newspaper, propagated Favoriten (Viennas $10^{\text {th }}$. district) as "Austria's crime hotspot"1, followed by the claim for a greater presence of police forces in the streets. Additionally, the editor in chief wrote a comment ${ }^{2}$ in the same issue which was very lurid and full of resentments. A few days later, das Biber, a multiethnic magazine, counters with a statement ${ }^{3}$ from a journalist who grew up in the concerned district. He confirmed that Favoriten is indeed not a posh district, but he rebuts most of the resentments. The controversy continued being broadly discussed on social media platforms and online forums.

1 Wilhelm Theuretsbacher: „Favoriten ist Österreichs heißestes Pflaster“ (Kurier, 13.10.2013).

2 Martina Salomon: „Mehr Augenmerk auf Problemregionen“ (Kurier, 13.10.2013).

3 Nour Khelifi: ,Wir Kinder aus dem Favoritner Ghetto“ (das Bieber, 14.10.2013,

http://www.dasbiber.at/content/wir-kinder-aus-dem-favoritner-ghetto).

Vogler, R., Car, A., Strobl, J. \& Griesebner, G. (Eds.) (2014): GI Forum 2014. Geospatial Innovation for Society. (c) Herbert Wichmann Verlag, VDE VERLAG GMBH, Berlin/Offenbach. ISBN 978-3-87907-545-4.

(C) ÖAW Verlag, Wien. eISBN 978-3-7001-7652-7, doi:10.1553/giscience2014s276. 
These exemplary discussions describe the main issue of the project Transforming Spaces: Breaking down social, cultural and planning barriers of Viennese adolescents in urban space utilisation very well. Vienna is a safe city with a high quality of life and numerous attractive places and recreational areas (ECONOMIST INTELLIGENCE UNIT 2011, MERCER 2011), but nevertheless certain spots are perceived as unattractive and/or unsafe (HÄBERLIN 2008, HOLZHACKER 2010). Connotations of these places are shaped by personal experience, the personal environment, peer groups, cultural aspects or the image drawn by various media (HÄBERLIN 2008), whereby personal experience is often underrepresented in this opinion-forming process.

Public space is an important place of action in the context of socio-spatial adoption processes and is particularly important for adolescents, providing a place away from parental control or the restrictions from school (MURI \& FRIEDRICH 2009). Young people use public space as roving and coping areas, as well as a kind of sanctuary to escape from highly controlled places like school or home (REUTLINGER 2003). While adults use public space primarily in a functional way, adolescents adopt places for more differentiated activities and purposes (KRISCH 2005). Therefore they are more affected by unattractive and unsecure places and situations. Results of various international studies point out, that particularly public space can have strong negative connotations caused by various factors. Bullying and gangs of other adolescents are the most cited aspects in these studies, next to fear of sexual harassment or abuse, and perceived insecurities due to descended neighbourhoods, homeless or drunk/drug addicts (JOHANSSON et al. 2012, MADGE 1997, PERCY-SMith \& MATTHEWS 2001, WoOLLEY et al. 1999). Negative connotations also often exist for districts with a high percentage of immigrant residents (HöGLHAMMER 2013). The degree of feeling or familiarity attached to a place has a strong impact on the individual perception of insecurities. Especially parental fears influence young people's perceived safety for a specific site (BROWNLOW 2005, HÖGLHAMMER 2013, JOHANSSON et al. 2012). Manifestations of fears are often related to gender, as bullying, violence or gang conflicts are particularly reported by men, while sexual harassment or abuse are mainly mentioned by women (BROWNLOW 2005, JOHANSSON et al. 2012).

Avoidance of places is the most common strategy for adolescents to react on perceived fears and insecurities in public spaces (BROWNLOW 2005, JOHANSSON et al. 2012, Matthews et al. 1998, Percy-Smith \& MAtThews 2001, Travlou 2003). Brownlow (2005) figured out that fears are more often caused on assumptions of potential risks than on lived experiences. Apart from avoidance, fears and insecurities can result in segregation, exclusion of social segments or increased requests for surveillance and control (HÖGLHAMMER 2013, LAUBE 2000, WEHRHEIM 2012).

\section{Project Goals}

The goal of the project Transforming Spaces is the identification of negatively associated places in Vienna, their distribution, extent, and spatial variability as well as the analysis of motives behind those appraisals. Based on these data, a dialog between different user groups on certain places shall be initiated. The comparison of an external view on negatively associated places with an internal view should help to reduce social, cultural and planning barriers. Derived strategies and recommendations for the Viennese planning authorities will support target-group specific urban space planning strategies and 
communication processes. By integrating the students from the beginning of the project, an insight into opinion-forming processes and individual site perceptions will be provided.

\section{Participatory Approach}

The project Transforming Spaces is based on a participatory research approach. Students are involved from the beginning of the project in each research step and are actively participating in the data collection of No-Go areas, as well as in the analysis, transformation, and self-reflection processes. They also support the scientific team in a target-group orientated adaption and application of the chosen methods.

The cooperation comprises four high schools in Vienna with different socio-spatial characteristics. In total, 162 students aged between 16-17 years are participating in the project. Because of the tight time schedule of school students, a good integration of the project in the different school curricula is essential. The major working packages with the students take place within blocked lessons, workshops and project days.

\section{Methods and Data Collection}

\subsection{Mix of methods}

To ensure a multi-perspective research approach we use a mix of qualitative and quantitative methods (e.g. focus groups, interviews, questionnaire, etc.). Participatory GISmethods (PPGIS, cognitive maps) are used for locating negatively associated places and for analysing their spatial variability and extent. To identify the reasons and motives of why and how places are perceived as unattractive or insecure, we are carrying out interviews, artistic approaches (e.g. GPS-Drawing, music style), as well as discussions on social network platforms. A dialog between different user groups of selected negatively associated places will be initiated within several focus groups. These discussions will build the base for the transformation process (see Fig. 1). Some applied methods are based on media and technologies linked directly to the use of communication devices and services of young people (e.g. PPGIS, GPS drawing, social networks, etc.).

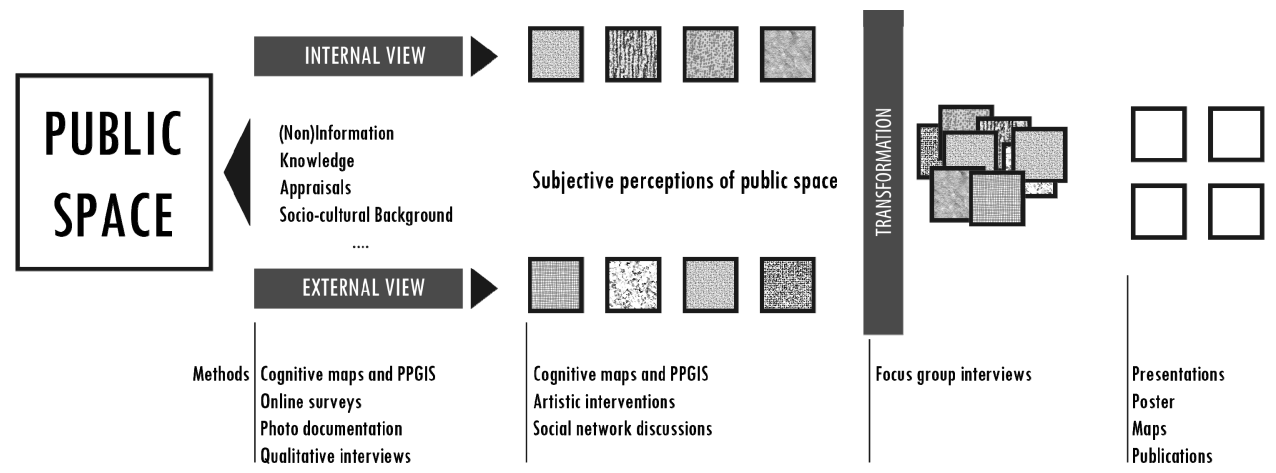

Fig. 1: Overview of the project workflow and the applied methods 


\subsection{Cognitive maps for identifying negative associated places}

There are many applications of cognitive maps for the analysis of research questions with a spatial context. In 1935 MUCHOW \& MUCHOW (1998) used cognitive maps to analyse the everyday environment of children in the city of Hamburg. Cognitive maps visualize perceptive properties that show how people react to their environment and how they conceptualize and arrange it (DOWNS \& STEA 1982, SCRUZZI 2010). Within the project I AM HERE! a web-mapping application named youth.places was developed to analyse the spatial behaviour of adolescents in Vienna (SCHAUPPENLEHNER et al. 2012). This application has been adapted for Transforming Spaces to create mental point maps for the identification of negatively associated places in Vienna. Students are encouraged to mark negative places as points and describe them using a short questionnaire.

In a first step, short workshops have been organised, where the students recorded their NoGo areas individually in the schools' computer labs, by entering data into the WebGIS application (see Fig. 2). As they are not in direct interaction with the particular places during this process, they had to describe their spots based on memories and imaginations. After the data recording, students were encouraged to record places directly on-site and on request. Therefore, we sent sporadic email messages to the students for several weeks, with the invitation to add and describe their current location. The technical approach for this method is based on a web application, which uses geo targeting to identify the current location of a person based on the IP address and/or the GPS location data when using a Smartphone or tablet.

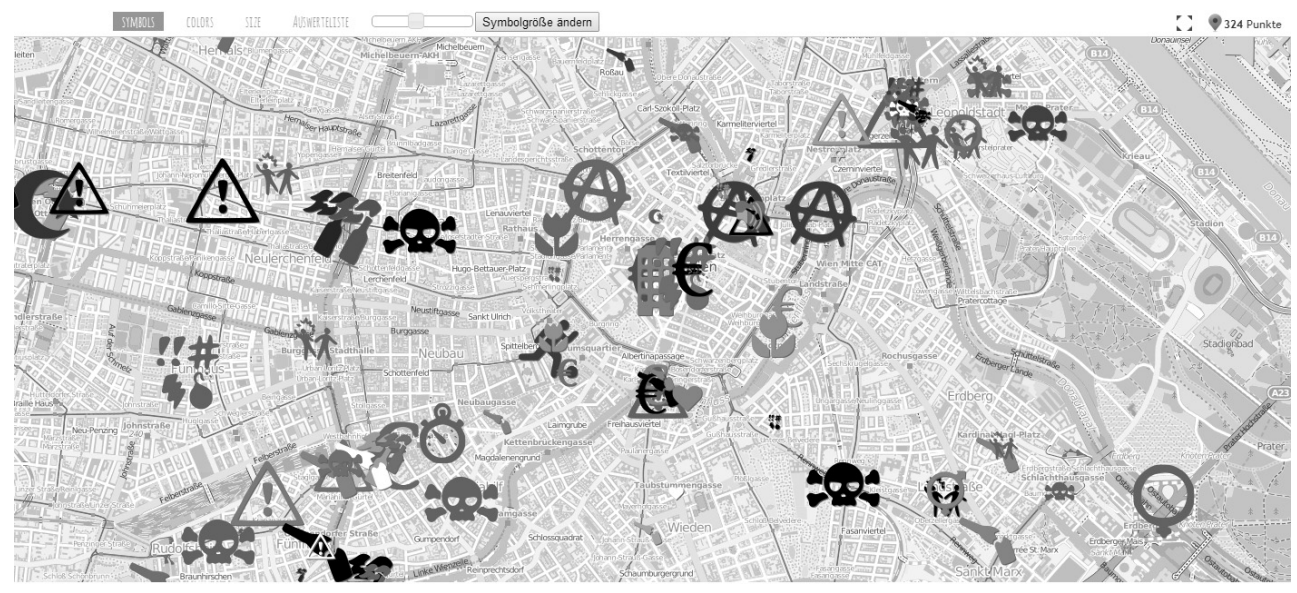

Fig. 2: Mental map for No-Go areas in Vienna $(n=324)$

\subsection{Land art approach (GPS Drawing) to express, experience and visualize spatial characteristics}

The land art approach using GPS devices creates art through walking (TUFNELL et al. 2002), with the goal of expressing feelings, expectations or perceptions regarding a specific place. GPS drawing was introduced by Hugh Pryor and Jeremy Wood and follows the idea of 
creating large-scale artworks within and depending on a specific landscape with the help of new media and technology (LAURIAULT \& WOOD 2009) - the GPS device is the "pen" and the landscape is the corresponding piece of "paper". By conducting the GPS drawing onsite, the students learn to see places in a new different way and it can enable them to experience spatial properties like topology, barriers and different viewpoints (SCHAUPPENLEHNER et al. 2013). Furthermore, it can help them to express their perceptions, opinions and feelings attached to a place, which is often challenging especially for adolescents (SCHAUPPENLEHNER et al. 2013). The artworks build a base for discussions on why places are negatively associated by the students. It should further support the students in exploring new areas within the city and transform their existing negative connotations about those yet unknown areas through experiencing them.

\subsection{Music associations to identify moods and feelings associated to places}

There is a significant correlation between music or music styles and place. Many music styles are established in very unique spatial, temporal and social settings that highly influence expression, style, content and message of the music (HALLAM et al. 2008, HUDSON 2006, KRIMS 2012). Place and associated activities also often claim a special music style. As such we choose different kinds of music in different settings and for different activities, but also associate different places with different kinds of music, and express our feelings regarding space with music (e.g. loud, quiet, fast, slow, dirty, conservative, ethnics, culture, etc.). A pilot test of this approach was conducted within the project I AM HERE! Students were asked to describe the public places they use with a specific music style. Results indicated that especially dense urban areas and places of consumption are much more diverse in music styles than parks or other green spaces. Places of control like school or home are described with more conservative styles. Water associated places which are often used for sport activities are dominated by fast and loud music styles (power music). Within Transforming Spaces a similar approach will be applied: Students are invited to characterise their No-Go areas with a song that expresses their emotions related to this area. Figure 3 shows a tag cloud with music styles associated with the marked places of the mental maps.

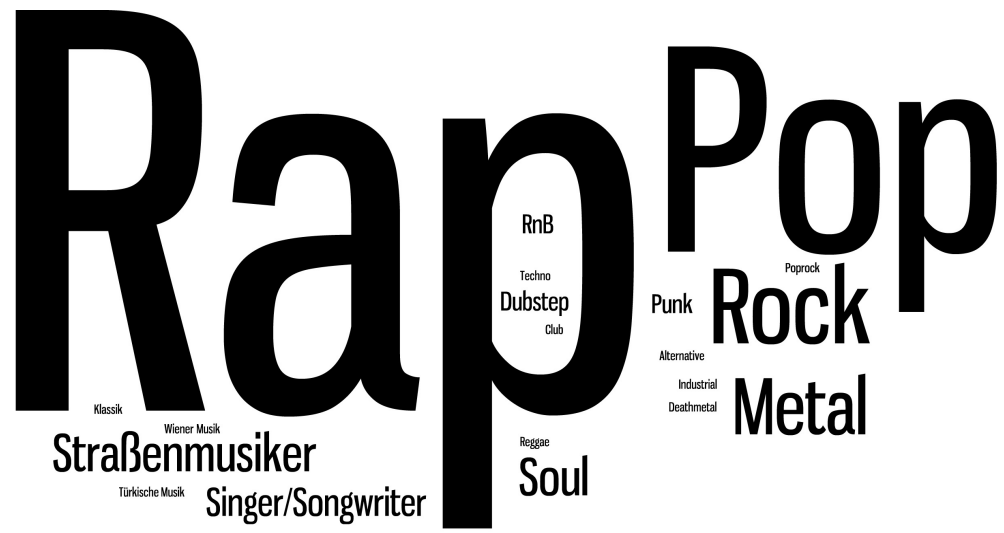

Fig. 3: Music styles associated with the No-Go areas marked in the mental maps $(\mathrm{n}=107)$ 
Thereby it was determined that Rap music is dominant, followed by Pop and different kinds of Rock music. The lyrics of the songs mentioned by the students often address places that represent danger or fear. Especially local rap artists frequently refer to particular places or districts and coquet with the bad image of certain spots - they are proud of "surviving" in those places.

\subsection{Social Networks to collect, discuss and share data and information}

Social networks such as Facebook and Twitter allow students to discuss their viewpoints with peers and to express their opinions by different ways of communication (e.g. photos, text, videos or music) (AYDIN 2012, FLICKER et al. 2008). A common problem when adolescents participate in research projects is to shape their understanding of why and how research questions and investigations concern their everyday life. Using social media in an educational context enhances the motivation of participants (AYDIN 2012) and helps them to connect the often abstract research questions with their personal environments.

So far, qualitative and quantitative methods are used to investigate perceptions and appropriations of public spaces of adolescents (ABBOTT-CHAPMAN \& ROBERTSON 2009, DUZENLI 2010, FITZGERALD et al. 1995, JOHANSSON et al. 2012, MÄKINEN \& TYRVÄINEN 2008). It is of current interest to identify the potential of social media regarding data collection and information gathering, as it could have several advantages. Students can express their perceptions and opinions without time constrictions, and data collection can take place in a long term period, compared to qualitative interviews, where data is collected with constraints in time and place. Furthermore, students can communicate their thoughts right in time and wherever they occur. This facilitates the collection of real-time emotions and opinions.

Within the project, students also act as peers as we encourage them to invite friends and colleagues, using mainly their (digital) social networks like Facebook or Twitter, to discuss No-Go areas. Thereby we will analyse how social media can be applied to record data for social science research questions.

Issues on privacy aspects and potential threats are an important topic in this context. "It only happens to the others" is a wide-spread attitude among adolescents, as they know about negative consequences regarding personal information in social networks, but have a very loose way of dealing with their own data (JUGENDKULTUR.AT 2010). Within the project we discuss these issues as well as the potential of social networks in participation processes.

\section{Challenges and Benefits of the Selected Approach}

The perception of negatively associated places is a very individual appraisal and is influenced by a broad range of factors. Common opinions, peers or media can highly influence individuals' perceptions of certain known or yet unknown places. Therefore, raising awareness and initiating self-reflection processes on external factors influencing perceptions can lead to real transformations of barriers and fears in the physical space, as many assumptions exist only in one's mind. 
The selected participatory and multi-perspective research approach offers advantages for this complex research question, as well as educational benefits in the field of spatial perception and GIS. The expert knowledge of the involved students is essential to answer the research questions and for the development of target-group orientated methods to motivate students to engage in participatory processes. Students are challenged to reflect their own opinions regarding their No-Go areas. Negotiation processes between stakeholder groups help to visualize the different viewpoints and circumstances, with the effect that prejudices can be minimised. As most previous studies focused on the motive of fear for the analysis of negatively associated places, this project treats different layers and motives.

The mix of methods allows a multi-dimensional view and supports the students in expressing their emotions on No-Go areas in different ways. Especially the artistic approaches encourage the students to visualise and illustrate their negative associations and emotions attached to places.

It is important to consider, that the chosen approach requires a high coordination effort between the scientific team and the participating schools, as well as a flexible project strategy to react on unpredictable circumstances. It is also challenging to overcome the gap between rigid school curricula and the required flexibility for the project work. Therefore, motivated researchers, teachers and students are essential for a successful project.

\section{Acknowledgement}

The project Transforming Spaces: Breaking down social, cultural and planning barriers of Viennese adolescents in urban space utilisation is funded by the "Stadt Wien - BOKU Research Funding".

\section{References}

AbBott-Chapman, J. \& Robertson, M. (2009), Adolescents' Favourite Places: Redefining the Boundaries between Private and Public Space. Space Cult., 12, 419-434.

AYDIN, S. (2012), A review of research on Facebook as an educational environment. Educ. Technol. Res. Dev., 60, 1093-1106.

Bosch, T. E. (2009), Using online social networking for teaching and learning: Facebook use at the University of Cape Town. Communication, 35, 185-200.

Brownlow, A. (2005), A geography of men's fear. Geoforum, 36, 581-592.

Downs, R. M. \& STEA, D. (1982), Kognitive Karten: Die Welt in unseren Köpfen. Harper \& Row.

Duzenli, T., BAyramoglu, E. \& ÖZBilen, A. (2010), Needs and preferences of adolescents in open urban spaces. Sci. Res. Essay, 5, 201-216.

ECONOMIST INTELLIGENCE UNIT (2011), Global Liveability Survey.

Fitzgerald, M., Joseph, A. P., Hayes, M. \& O’Regan, M. (1995), Leisure activities of adolescent schoolchildren. J. Adolesc., 18, 349-358.

Flicker, S., Maley, O., Ridgley, A., Biscope, S., Lombardo, C. \& Skinner, H. A. (2008), e-PAR: Using technology and participatory action research to engage youth in health promotion. Action Res., 6, 285-303. 
HÄBERLIN, U. W. (2008), (Un)Sicherheit und Urbanität (No. 11). Wien, Beiträge zur Stadtentwicklung, MA 18, Stadtentwicklung und Stadtplanung.

Hallam, S., Cross, I. \& Thaut, M. (2008), Oxford Handbook of Music Psychology. Oxford University Press.

HöGlHAMmer, A. (2013), Jugend(t)räume - Eine qualitative Studie zur Raumwahrnehmung und -aneignung von Jugendlichen in Wien Diploma Thesis, Universität für Bodenkultur, Wien.

HOLZHACKER, C. (2010), Sozialraumanalyse Wien - Ottakring: Jugendzone 16. Expedition JugendZone, Wien.

Hudson, R. (2006), Regions and place: music, identity and place. Prog. Hum. Geogr., 30, 626-634.

Johansson, K., Laflamme, L. \& Eliasson, M. (2012), Adolescents' Perceived Safety and Security in Public Space - A Swedish Focus Group Study with a Gender Perspective. Young, 20, 69-88.

JugendKultur.AT (2010), Chancen und Gefahren von Online Communities, quantitative Ergebnisse. Jugendkultur.at.

KHELIFI, N. (2013), Wir Kinder aus dem Favoritner Ghetto. Biber.

KRIMS, A. (2012), Music and Urban Geography. Routledge.

KRISCH, R. (2005), Sozialräumliche Perspektiven der Jugendarbeit. In: BRAUN, K.-H. \& Wetzel, K. (Eds.), Handbuch Methoden der Kinder- und Jugendarbeit. Studien zur Pädagogischen Entwicklungsforschung und Qualitätssicherung. Wien, 336-351.

LAUBE, V. (2000), "Sicherheit" als strukturierendes Merkmal städtischer Entwicklung Konsequenzen für den urbanen Raum. Diplomarbeit, Universität, Bremen.

Lauriault, T. P. \& Wood, J. (2009), GPS Tracings - Personal Cartographies. The Cartographic Journal, 46 (4), 360-365.

MadGe, C. (1997), Public Parks and the Geography of Fear. Tijdschr. Voor Econ. En Soc. Geogr., 88, 237-250.

MÄKINEN, K. \& TYRVÄINEN, L. (2008), Teenage experiences of public green spaces in suburban Helsinki. Urban For. Urban Green., 7, 277-289.

Matthews, H., Limb, M., Percy-Smith, B. (1998), Changing Worlds: the Microgeographies of Young Teenagers. Tijdschr. Voor Econ. En Soc. Geogr., 89, 193-202.

MERCER (2011), Quality of living reports - 2011 edition.

Muchow, M. \& Muchow, H. H. (1998), Der Lebensraum des Grossstadtkindes. Juventa.

MURI, G. \& FRIEDRICH, S. (2009), Stadt(t)räume - Alltagsräume? Jugendkulturen zwischen geplanter und gelebter Urbanität. Wiesbaden, VS Verlag für Sozialwissenschaften/ GWV Fachverlage.

PerCy-Smith, B. \& MAtThews, H. (2001), Tyrannical Spaces: Young people, bullying and urban neighbourhoods. Local Environ., 6, 49-63.

Reutlinger, C. (2003), Jugend, Stadt und Raum: sozialgeographische Grundlagen einer Sozialpädagogik des Jugendalters. VS Verlag.

Schauppenlehner, T., Blamhofer, S., Horn, M., Ogris, A., Schuhmacher, C., HöglHammer, A., Muhar, A., Eder, R., Taczanowska, K. (2012), Can We Make an App for that? Integration of School Students within a Research-education Cooperation. In: Jekel, T., Car, A., Strobl, J., Griesebner, G. (Eds.), GI_Forum 2012: Geovisualization, Society and Learning. Berlin/Offenbach, Wichmann, 222-229. 
Schauppenlehner, T., Höglhammer, A., Muhar, A. \& Eder, R. (2013), Rethinking Urban Space: GPS Drawing as a Tool to Examine Spatial Patterns and Relationships. In: Jekel, T., Car, A., Strobl, J. \& Griesebner, G. (Eds.), Creating the GiSociety Conference Proceedings. Berlin/Offenbach, Wichmann, 399-406.

SCRUZZI, D. (2010), Eine Stadt denkt sich die Welt: Wahrnehmung geographischer Räume und Globalisierung in Venedig von 1490 bis um 1600. Akademie Verlag.

Travlou, P. (2003), Teenagers and Public Space - Literature Review. OPENspace.

Tufnell, B., Wilson, A., McKibBen, B. \& ScotT, D. K. (2002), Hamish Fulton: Walking Journey. London, Tate Publishing.

WehrheIM, J. (2012), Die überwachte Stadt: Sicherheit, Segregation und Ausgrenzung. Opladen, Budrich.

Woolley, H., Dunn, J., Spencer, C., Short, T. \& Rowley, G. (1999), Children describe their experiences of the city centre: a qualitative study of the fears and concerns which may limit their full participation. Landsc. Res., 24, 287-301. 